\title{
The Impact of Human \\ Rights Law on General International Law
}

\author{
Edited by
}

MENNO T. KAMMINGA

and

MARTIN SCHEININ 


\section{Contents}

Preface

List of Abbreviations

Table of cases

1. Final Report on the Impact of International Human Rights Law on General International Law Menno T. Kamminga

2. Impact on the Law of Treaties Martin Scheinin

3. Impact on General Principles of Treaty Interpretation Jonas Christoffersen

4. Impact on the Law on Treaty Reservations Ineke Boerefijn

5. Impact on State Succession in Respect of Treaties Menno T. Kamminga

6. Impact on the Process of the Formation of Customary International Law Jan Wouters and Cedric Ryngaert

7. Impact on the Structure of International Obligations Sandesh Sivakumaran

8. Impact on the Immunity of States and their Officials Thilo Rensmann

9. Impact on the Right to Consular Notification Christina M. Cerna

10. Impact on the Law of Diplomatic Protection Riccardo Pisillo Mazzeschi

11. Impact on State Responsibility Robert McCorquodale 